\title{
REPORT OF THE COUNCIL
}

\author{
or \\ THE CAMDEN SOCIETY, \\ READ AT THE GENERAL MEETING \\ ON THE 2ND MAY, 1874.
}

Tre Council of the Camden Society elected on the 4th of June 1873 have deeply to regret the loss of

\section{John Govgh Nichols, Esq. F.S.A.}

Mr. Nichols was one of the Original Founders of the Society. The want of any means of printing and circulating historical books, which no Bookseller would undertake the risk of publishing, had for some time engaged his attention, in common with the late Mr. Bruce, Mr. Wright, and other literary men. The result of a consultation between these gentlemen in 1838 was the plan of the Camden Society, which met with the hearty approval of Mr. Amyot, Dr. Bliss, Mr. Purton Cooper, and others, who took a warm interest in promoting its success, and it was formally established at a meeting held at the house of Mr. Nichols in Parliament Street, where the members of the Society have always met with a hospitable reception.

Of the services of Mr. Nichols as the Printer of the Society, and one of the most industrious and intelligent of its editors, it is hardly necessary to speak. When he died, two books, The Autobiography of Lady Halket and The Sermons of the Boy Bish'p, were in his hands, and the numerous notes of all kinds which he left for his own use in editing them will be a monument of painstaking industry and deep erudition, whilst 
many of them are but too likely to prove, from their brevity, unintelligible to those who have to read the riddle without the power of appealing to the interpreter, who alone possessed the clue.

The death of Mr. Albert Way, formerly one of our Members, and who was the Editor of the Promptorium Parvulorum, one of the most valuable of our publications, has also been a matter of deep regret to the Council, and will, they feel certain, be shared by the Society at large.

The following Members of the Society, they are sorry to add, have also died within the last year :-

\author{
Daniel Benham, Esq. \\ P. H. Fisher, Esq. \\ Frederic Gwation, Esq. \\ James Rober'T Scott Hope, Esq., D.C.L. \\ Rev. J. WILsoN, D.D.
}

The following have been the Books issued to the Subscribers during the past year:-

I. A Military Memoir of Colonel Birch. Edited by the late Rev. JoHN WEBB and the Rev. T. W. Weвb.

This volume, of which the Commentary, which was the work of the last days of the Rev. John Webb, is the principal feature, is a storehouse of curious facts relating to the period of the Civil War.

II. and III. Letters addressed from London to Sir Joseph Williamson while Plenipotentiary at the Congress of Cologne in the year 1673. Edited by W. D. Christie, C.B.

These volumes are full of news of an interesting and personal character from the Court of Charles II.

In addition to the two books mentioned above as being left in a state of preparation by Mr. Nichols, the Society has by the kindness of Mr. Thoms, the executor of the late Mr. Bruce, been put in possession of a collection of papers left in an unfinished state by its late Director. Of 
these the most nearly complete series is composed of documents relating to the dispute between Cromwell and the Earl of Manchester in 1644, for which the greater part of the Preface is already written, and for which Professor Masson has consented to add such introductory matter as may still be found necessary. Besides, there are a few papers relating to the Starchamber sentence upon Prynne, to which a fragment of the biography of Prynne may serve as a Preface. There is also a collection of State papers relating chiefly to the marriage of Charles I. and the early years of the reign of that King, with an historical fragment on that period.

The books for the year 1874-5 will probably be-

I. Account of the Executors of Richard Bishop of London 1303 and of the Executors of Thomas Bishop of Exeter 1310. Edited by the late Archdeacon Hale and The Rev. H. T. Ellacombe.

II. Papers relating to the Quarrel between Oliver Cromwell and the Earl of Manchester. Edited by the late JoHn Bruce.

III. The Seventh Volume of the Camden Miscellany, containing, amongst other matters, The Accounts of the Building of the Church of Bodmin. Edited by the Rev. J. Wilkinson, Rector of Lanteglos. 2. Papers relating to the Sentence upon Prynne. Edited by the late John Bruce. 3. Sermons of the Boy Bishop. Edited by the late J. G. Nichols and Dr. Rimbault.

The Council have thought that they would best meet the wishes of the Society by placing in the hands of Members books which have occupied the thoughts of those who have laboured so much for their interests as Mr. Bruce, Mr. Nichols, and Archdeacon Hale. The Chronicle of England from Lord Henry Percy's MS. will thus be unavoidably postponed for another year. It may, however, be satisfactory to the Society to know that time has not been lost, and that the result of Mr. Hamilton's investigations has been to show that the Chronicle is not a mere abridgment of Stow, but the original from which Stow derived a great part of his information, and that it is even more valuable as giving the impression made upon an ordinary citizen by passing occurrences in the reigns of Henry VIII., Edward VI, and Mary, than from its narrative of events. 
The following work has been added to the list of Suggested Publications :-

Papers relating to the Court of High Commission in the time of Charles I. To be Edited by L. O. Prke, Esq.

These papers were collected by the late Mr. Bruce, but he had taken no steps towards editing them. The interest of papers in which men like Laud and Abbot freely express their opinions on ecclesiastical matters can be easily conceived.

In conclusion, the Council would again urge upon Members of the Society the propriety of making known as widely as possible the work which is being done, in order that support may be given to the much greater work which is still to be done.

\author{
By Order of the Council, \\ Samuel Rawson Gardiner, Director. \\ Alfred Kingston, Hon. Secretary.
}




\section{REPORT OF THE AUDITORS.}

$W_{E}$, the Auditors appointed to audit the Accounts of the Camden Society, report to the Society, that the Treasurer has exhibited to us an Account of the Receipts and Expenditure from the 18th of April 1873 to the 16th of April 1874, and that we have examined the said accounts, with the vouchers relating thereto, and find the samc to be correct and satisfactory.

And we further report that the following is an Abstract of the Receipts and Expenditure during the period we have mentioned :-

RECEIPTS. E s. d.

To Balance of last year's account. . $544 \quad 311$

Received on account of Members whose Subscriptions were in arrear at last Audit ................. due on the lst of May, $1873 \ldots 267$

The like on account of Subscriptions due on the lst of May, 1874....

To one Composition in lieu of Annual Subscription ..............

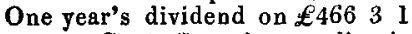
3 per Cent. Consols, standing in the names of the Trustees of the Society, deducting Income Tax. .

To Sale of the Publications of past years.................................

To Sale of Promptorium Parvulorum (3 vols. in 1) .......................

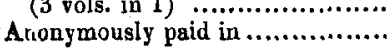

EXPENDITURE.

s. $d$.

Paid for printing 500 copies Commons Debates in 1625 ...................................................

$4800 \quad$ Paid for printing 500 copies Letters to Sir Joseph

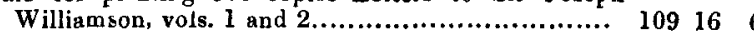

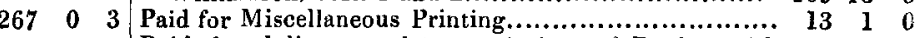

Paid for delivery and transmission of Books, with

2100 paper for wrappers, warehousing expenses (in-

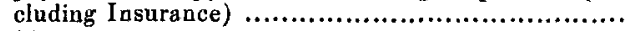

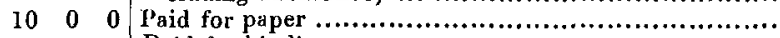

Paid for binding

Paid for Transeript of Venetian Dispatches, 1623 to

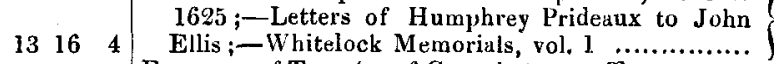

Expenses of Transfer of Consols to new Trustees ......

151,4 One Subscription returned (twice paid) .................

Paid for postages, collecting, conntry expenses, \&c. ...

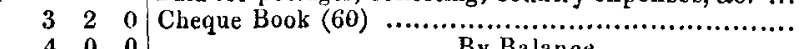

By Balance

$5914 \quad 9$

$\begin{array}{lll}80 & 3 & 3\end{array}$

$2614 \quad 4$

$3812 \quad 0$

g1 190

$\begin{array}{lll}45 & 13 & 0\end{array}$

$\begin{array}{lll}3 & 4 & 0\end{array}$

100

$513 \approx$

$\begin{array}{lll}0 & 5 & 0\end{array}$

$\lcm{£ 926 \quad 3 \quad 10}$

And we, the Auditors, further state, that the Treasurer has reported to us, that over and above the present balance of $£ 5207 s .10 d$. there are outstanding various subscriptions of Foreign Members, and of Members resident at a distance from London; which the Treasurer sees no reason to doubt will shortly be received.

HeNRY HiLl. George F. Smith. 